\title{
Nutritional properties of cherry tomatoes harvested at different times and grown in an organic cropping
}

\author{
Lucinéia de Pinho$^{1}$; Anna Christina Almeida ${ }^{1}$; Cândido A Costa ${ }^{1}$; Maria Cristina D Paes²; Maria Beatriz \\ A Glória ${ }^{1}$; Rogério Marcos Souza ${ }^{1}$ \\ ${ }^{1} U F M G$, C. Postal 135, 39404-006 Montes Claros-MG, lucineiapinho@hotmail.com; ${ }^{2}$ Embrapa Milho e Sorgo, C. Postal 151, 35701-970 \\ Sete Lagoas-MG
}

\begin{abstract}
The physicochemical characteristics of the cherry tomato cultivated in organic and conventional production systems and harvested at either 30 or 45 days of cropping were evaluated using a randomized, $2 \times 2$ factorial design ( 2 cropping systems $\mathrm{x} 2$ harvesting times) with five repetitions. The parameters analyzed were color, centesimal composition, total energetic value, carotenoids and bioactive amine content. Tomatoes harvested at 30 days had higher total soluble solid (TSS) content when grown conventionally, but when harvested at 45 days, both conventional and organic tomatoes had similar TSS values, probably due to increased $\mathrm{N}$ availability in the soil. Organic cherry tomatoes had higher contents of $\beta$-carotene, lycopene and bioactive amine. On the other hand, tomatoes from conventional cropping were more alkaline and brighter. In conclusion, organic tomatoes are more nutritious than conventional varieties, and if allowed to ripen for up to 45 days, contain higher levels of TSS, carotenoids and total bioactive amines.
\end{abstract}

Keywords: Solanum lycopersicum, nutricional value, quality.

\section{RESUMO}

Propriedades nutricionais de tomates cereja colhidos em diferentes épocas e cultivado em sistema orgânico

As características físico-químicas de tomates cereja cutivados em sistema orgânico e convencional e colhidos em 30 ou 45 dias de cultivo foram avaliadas em um delineamento casualizado, fatorial $2 \times 2$ ( 2 sistemas de cultivo x 2 épocas de colheita) com cinco repetições. Foram analisados os parâmetros cor, composição centesimal, valor energético total e conteúdo de carotenóides e de aminas bioativas. Tomates colhidos em 30 dias tiveram maior conteúdo de sólidos solúveis totais (SST), possivelmente devido ao aumento de disponibilidade de $\mathrm{N}$ no solo. Os tomates orgânicos tiveram maior conteúdo de $\beta$-caroteno, licopeno e aminas bioativas. Por outro lado, os tomates convencionais foram menos ácidos e tiveram maior brilho. Conclui-se que tomates orgânicos são mais nutritivos que os convencionais, e se amadurecerem até 45 dias concentram maior teor de SST, carotenóides e aminas bioativas totais.

Palavras-chave: Solanum lycopersicum, valor nutricional, qualidade.

(Recebido para publicação em 7 de abril de 2010; aceito em 6 de maio de 2011) (Received on April 7, 2010; accepted on May 6, 2011)

$\mathrm{T}$ he growing demand for high quality vegetables has increased investment in new production techniques. This includes the development of organic cropping systems as a replacement for the conventional system, which uses high amounts of fertilizer and agrochemical input to guarantee productivity even though they are known to compromise both the environment and human health (Borguini \& Silva, 2007). In this scenario, the agroecology provides a scientific basis for ecological production systems. It sets suitable designs for agrosystems, considering environmental, economic, social, ethical, political and cultural dimensions, from the perspective of sustainability and production of betterquality food (Kokuszka, 2005). In this respect, the organic cropping system is an ecologically correct agricultural practice with potential for producing highly nutritional vegetables despite the lack of chemical fertilization.

A main product in organic cropping systems is the tomato. The tomato, one of the most important vegetables grown in Brazil (Marim et al., 2001), has seen increased demand in recent years and good financial returns for farmers (Lenucci et al., 2006). Nevertheless, information on the physicochemical, microbiological and nutritional attributes of this product is still scarce, especially for organically grown varieties (Borguini \& Silva, 2007). Furthermore, most available results diverge widely due to the cropping system (organic $v s$ conventional) as well as natural variations in maturation and environmental factors that are known to affect tomatoes and other vegetable cultures (Mercadante et al., 1997).

Various studies were conducted to investigate the nutritional value of vegetables, focusing on fertilizer type or even using food from grocery stores. However, these investigations did not produce conclusive answers regarding the impact of the organic and conventional production system on the nutritional value of vegetables. Although important, comparisons among fertilizers consider a single production factor, the fertilization, whereas analyses of grocery products grossly overlook the origin of the products (Borguini \& Torres, 2006).

Considering the above mentioned facts, in this study we evaluated the physicochemical and nutritional characteristics of cherry tomatoes produced simultaneously in organic and conventional cropping systems. Because there is evidence that tomato properties vary over the harvesting period, cherry 
tomatoes were harvested at two different ages: 30 and 45 days.

\section{MATERIAL AND METHODS}

The cherry tomato analyzed in this study, cultivar Carolina, was cultivated in both organic and conventional systems, in the experimental area of the Universidade Federal de Minas Gerais, in Montes Claros, Minas Gerais State, Brazil, from June to October 2006. The treatments were arranged in a completely randomized $2 \times 2$ factorial design, corresponding to two harvest times (30 and 45 days after initial fruit ripening) and two cropping systems (organic and conventional), with five repetitions. To ensure identical climatic conditions, the different cropping systems were applied to two homogeneous fields in a same area (18 plots of $4 \times 4 \mathrm{~m}$ in each field). These fields were separated by a minimum distance of $500 \mathrm{~m}$, as determined by the Brazilian Federal Law (Brazil, 2003).

The plot used to implement the organic system had been used for conventional cropping and subjected to the usual management procedures. However, this plot was allowed to lie fallow for 5 years before the experiment, as recommended by the Brazilian legislation regarding organic crops (Brazil, 2003). Soil in both plots was prepared using moldboard and blade plow, and green manure was added to the organic soil. The ground in the plot used for conventional cropping was sprayed with herbicides applied according to manufacturer's instructions.

Tomato seedlings were planted 1.0 x $0.7 \mathrm{~m}$ apart, with a total of 24 plants in each plot. The conventional cropping plot received NPK $+\mathrm{Zn}$ fertilization $\left(\mathrm{N}=8 ; \mathrm{P}_{2} 0_{5}=28 ; \mathrm{K}_{2} 0=16\right)$, and urea was applied to the bare soil. In the organic plot the fertilizer used was fresh chicken and cattle manure and Cameron grass (Pennisetum schum) at a 1:2:7 ratio and natural Mercofertil® phosphate $(29 \%$ $\left.\mathrm{P}_{2} \mathrm{O}_{5} ; 36 \% \mathrm{Ca}\right)$.

Both plots were drip irrigated, ensured adequate watering. Weeds were hand removed in the organic system, with pest control managed using a
Neem-based solution (Azadirachta indica) to control arthropods, Bordeaux mixture to prevent pathogenic fungi and biofertilizers to nourish and prevent diseases. In the conventional system, commercial pesticides were used for pest and disease control and sprayed at a dosage and periods recommended by the manufacturer for tomato cropping. The experiment began when tomato plants were $2 \mathrm{~m}$ in height.

Soil characteristics in the organic soil were: organic matter $=60.1 \mathrm{~g} / \mathrm{kg}$; $\mathrm{pH}=6.8$; available $\mathrm{P}=48.5 \mathrm{mg} \mathrm{dm}^{-3}$; $\mathrm{K}=409 \mathrm{mg} \mathrm{dm}{ }^{-3} ; \mathrm{Ca}=8.3\left(\mathrm{cmol}_{\mathrm{c}} \mathrm{dm}^{-}\right.$ $\left.{ }^{3}\right)^{2}$; and $\mathrm{Mg}=3.90\left(\mathrm{cmol}_{\mathrm{c}} \mathrm{dm}^{-3}\right)^{2}$. In the conventional soil, organic matter $=38.8$ $\mathrm{g} / \mathrm{kg} ; \mathrm{pH}=5.4$; available $\mathrm{P}=6.7 \mathrm{mg} \mathrm{dm}^{-3}$; $\mathrm{K}=153 \mathrm{mg} \mathrm{dm}^{-3} ; \mathrm{Ca}=3.3\left(\mathrm{cmol}_{\mathrm{c}} \mathrm{dm}^{-3}\right)^{2}$; and $\mathrm{Mg}=1.50\left(\mathrm{cmol}_{\mathrm{c}} \cdot \mathrm{dm}^{-3}\right)^{2}$.

Approximately $10 \mathrm{~kg}$ of tomato fruits were harvested from 5 plots randomly selected in each cropping system on each harvesting date (30 and 45 days). Only the central plants of each plot were sampled. The fruits were randomly collected in the morning, but considering characteristics such as uniformity of color, degree of maturation and absence of disease and injury. Plastic bags were used to collect and store the tomatoes to avoid manual contact. Tomatoes were then washed in fresh distilled water and dried immediately with paper towel. Next, they were quartered, homogenized in a blender and placed in lidded sterile flasks. Part of the mix was immediately used to determine physicochemical characteristics and the rest stored at $-18^{\circ} \mathrm{C}$ for further analysis.

Analyses of the antioxidant compounds and bioactive amines were conducted in duplicate and nutritional and physicochemical analyses in triplicate. Analyses were carried out in the laboratories of Embrapa Milho e Sorgo, Sete Lagoas, Minas Gerais State and of the Universidade Federal de Minas Gerais, Belo Horizonte, Minas Gerais State.

The total soluble solids content (TSS) ( ${ }^{\circ}$ Brix) was determined using a digital refractometer (Atago ${ }^{\circledR}$ model $\mathrm{N}-1 \mathrm{E}$ ) (AOAC, 2000); the $\mathrm{pH}$ was determined using a digital Phmeter (Quimis $^{\circledR}$, model Q-400HM portable), according to official AOAC norms (2000); the total titratable acidity (TTA) was determined as mg of citric acid 100 $\mathrm{g}^{-1}$ of pulp in accordance to IAL (1985); the color was determined with the Hunter scale using a digital colorimeter (Color tec PCM). We analyzed the $\mathrm{L}^{*}$ component of shine intensity, which varies from white (100) to black (0), differentiating clear from dark colors; the $\mathrm{a}^{*}$ component, which varies from $-\mathrm{a}^{* *}$ (green color degree) to $+\mathrm{a}^{*}$ (red color degree), and the $b^{*}$ component, which varies from $-b^{*}$ (blue color degree) to $+b^{*}$ (yellow color degree).

The Centesimal Composition is the determination of humidity, ashes, crude fiber, protein and ethereal extract (AOAC, 2000). Carbohydrate content was calculated by subtracting humidity rate, ethereal extract, protein, crude fiber and ashes from a $100 \mathrm{mg}$ sample. Dry matter content was determined by subtracting humidity rate from $100 \mathrm{mg}$ of food.

Total Energetic Value was calculated based on Atawer conversion factors, which considers $4 \mathrm{kcal} / \mathrm{g}$ of protein, 4 $\mathrm{kcal} / \mathrm{g}$ of carbohydrate and $9 \mathrm{kcal} / \mathrm{g}$ of lipid (Lima et al., 2007).

Carotenoids: total carotenoid content, $\beta$-carotene and lycopene were determined using a chromatographic/ spectophotometric protocol as described by Rodriguez-Amaya \& Kimura (2004). Carotenoid concentrations were expressed on a fresh weight basis $\left(\mu \mathrm{g} \mathrm{g^{-1 }}\right)$.

Bioactive amines: putrescine, cadaverine, tyramine, histamine, serotonine, agmatine, spermidine, spermine, feniletilamine and tryptamine amines were extracted with 5\% trichloroacetic acid, separated by CLAE (ion exchange column) and quantified fluorimetrically at $340 \mathrm{~nm}$ of stimulation and $445 \mathrm{~nm}$ of emission (Vale \& Gloria, 1997). Amine concentrations were expressed on a fresh weight basis ( $\mu \mathrm{g}$ $\left.\mathrm{g}^{-1}\right)$.

Physicochemical data on tomatoes from different treatments were analyzed using factorial analysis of variance (ANOVA). Differences among the means detected at a significance level of $\mathrm{p} \leq 0.05$ were compared using Tukey's test. 


\section{RESULTS AND DISCUSSION}

Total soluble solids (TSS) content of cherry tomatoes was affected by the interaction between harvesting time and production system $(\mathrm{p}<0.05)$. At the first harvesting (30 days), tomatoes from the conventional system had higher levels of TSS compared to their organic counterparts, but these levels were comparable at the second harvesting (45 days), when overall values in both systems increased (Table 1).

Mechanical pressure relief and impact on the fruits may explain the TTS increase over the experiment. Although this was not quantified, a higher number of fruits was observed at the first harvesting (at 30-day cropping). Earlier studies hypothesized that high fruit density favors mechanical damage and physicochemical alterations (Ferreira et al., 2005), possibly influencing tomato quality. Corroborating this assumption, Caliman et al. (2008) state that TSS content is inversely proportional to tomato tree production. The results of the present study are in accordance with these arguments because after 45 days cropping, when fewer tomatoes were observed on the plants, the fruit contained higher levels of carbohydrates and other soluble compounds.

The TSS of conventional tomatoes increased before that of the organic variety. Nitrogen $(\mathrm{N})$, which is known to enhance TSS, is available in organic systems only after mineralization processes. In the present study, mineralization followed by $\mathrm{N}$ absorption in the organic treatment occurred after more than 30 days, whereas $\mathrm{N}$ was promptly available in the fertilizer used in the conventional crop. After 45 days cropping, $\mathrm{N}$ availability and TTS levels were similar between the cropping systems.

On the other hand, potassium, which lowers TSS, is available for the organic crop from the moment that organic matter is applied (Chitarra \& Chitarra, 2005). This was reinforced by the fact that high P levels were detected in the soil used for organic cropping. But this was later compensated, probably due to the increase in $\mathrm{N}$ caused by

Table 1. Mean $( \pm \mathrm{sd})$ total soluble solids $\left({ }^{\circ} \mathrm{Brix}\right), \mathrm{pH}$, total titratable acidity (mg of citric acid $100 \mathrm{~g}^{-1}$ ) and $\mathrm{L}^{*}, \mathrm{a}^{*}$ and $\mathrm{b}^{*}$ color components of cherry tomatoes from conventional or organic crop (sólidos solúveis, $\mathrm{pH}$, acidez total titulável e $\mathrm{L}^{*}, \mathrm{a}^{*} \mathrm{e} \mathrm{b}^{*}$ de tomate cereja cultivado em sistemas de produção orgânico e convencional). Montes Claros, UFMG, 2006.

\begin{tabular}{|c|c|c|}
\hline Variable & 30 days & 45 days \\
\hline \multicolumn{3}{|c|}{ Total soluble solids ( $\left.{ }^{\circ} \mathrm{Brix}\right)$} \\
\hline Organic & $4.0 \pm 1.0 \mathrm{Bb}$ & $6.0 \pm 0.0 \mathrm{Aa}$ \\
\hline Conventional & $5.2 \pm 0.4 \mathrm{Ab}$ & $6.1 \pm 0.2 \mathrm{Aa}$ \\
\hline \multicolumn{3}{|l|}{ pH } \\
\hline Organic & $4.4 \pm 0.1$ & $4.3 \pm 0.0 \mathrm{~B}$ \\
\hline Conventional & $4.6 \pm 0.1$ & $4.5 \pm 0.2 \mathrm{~A}$ \\
\hline \multicolumn{3}{|c|}{ Total titratable acidity (mg of citric acid $\left.100 \mathrm{~g}^{-1}\right)$} \\
\hline Organic & $335.7 \pm 15.8$ & $340.1 \pm 7.7$ \\
\hline Conventional & $329.2 \pm 9.4$ & $330.1 \pm 12.3$ \\
\hline \multicolumn{3}{|l|}{$\mathbf{L}^{*}$} \\
\hline Organic & $29.7 \pm 2.9$ & $33.3 \pm 1.6$ \\
\hline Conventional $^{\dagger}$ & $35.4 \pm 3.2$ & $35.3 \pm 3.3$ \\
\hline \multicolumn{3}{|l|}{$a^{*}$} \\
\hline Organic & $14.7 \pm 4.2$ & $17.7 \pm 8.5$ \\
\hline Conventional & $16.5 \pm 7.2$ & $14.6 \pm 2.1$ \\
\hline \multicolumn{3}{|l|}{$\mathbf{b}^{*}$} \\
\hline Organic & $24.0 \pm 6.3$ & $28.7 \pm 5.4$ \\
\hline Conventional & $31.8 \pm 7.5$ & $32.7 \pm 9.0$ \\
\hline
\end{tabular}

'indicates difference between the crop systems; means followed by different lowercase letter in a column are different; means followed by different uppercase letter in a row are different (Tukey's test, $\mathrm{p}<0.05$ ). The results are expressed on a fresh weight basis ('indica diferença entre os sistemas de cultivo; médias seguidas por diferentes letras minúsculas em uma coluna são diferentes; médias seguidas por diferentes letras maiúsculas em uma linha são diferentes (teste de Tukey, $\mathrm{p}<0.05$ ). Os resultados são expressos com base em peso fresco).

mineralization.

Tomato $\mathrm{pH}$ was affected by the cropping system but not by harvesting time. Cherry tomatoes cultured in the conventional system had a slightly higher $\mathrm{pH}$ (4.5) than organic tomatoes $(\mathrm{pH}=4.3)(\mathrm{p} \leq 0.05)($ Table 1$)$. Despite the statistical significance, this difference is not biologically relevant. Fruits with $\mathrm{pH}$ values of up to 4.5 are classified as acidic and generally considered to have appreciable smell and taste (Gould, 1974).

Total titratable acidity of the tomatoes was not affected by any of the factors studied. Treatments showed a mean value of $333.8 \pm 11.6 \mathrm{mg}$ of citric acid (Table 1), which is within the acceptable range.

According to Chitarra \& Chitarra (2005), vegetable color can be evaluated through subjective methods. This is the case for the color scale used in the present study. Following this procedure, component $\mathrm{L}^{*}$ of this scale was found to be affected by the production system, without any interference from harvesting time. Components $a^{*}$ and $b^{*}$ were not affected by the experimental factors tested $(\mathrm{p}<0.05)$. Component $\mathrm{L}^{*}$, which indicates luminosity within a 100 (white) to 0 (black) range, was higher in tomatoes produced under the conventional system than in organic tomatoes $(\mathrm{p} \leq 0.05)$ (Table 1), i.e., conventional tomatoes were brighter.

In general, $\mathrm{L}^{*}$ value decreases as tomatoes ripen and turn red because carotenoid synthesis and loss of green color decreases fruit brightness (Carvalho et al., 2005). The low L* value in tomatoes grown under the organic system is likely associated to their carotenoid content, which was higher than in conventional tomatoes, as will be discussed later. According to 
Table 2. Mean $( \pm \mathrm{sd})$ total carotenoids, $\beta$-carotene and lycopene $\left(\mu \mathrm{g} \mathrm{g}^{-1}\right)$ of cherry tomatoes from conventional or organic crop (carotenóides totais, $\beta$-caroteno e licopeno de tomate cereja cultivado em sistemas de produção orgânico e convencional). Montes Claros, UFMG, 2006.

\begin{tabular}{lcc}
\hline Component & 30 days & 45 days \\
\hline Total Carotenoids $\left(\boldsymbol{\mu g ~ \mathbf { g } ^ { - 1 } )}\right.$ & & \\
\hline Organic & $47.98 \pm 1.66 \mathrm{Ab}$ & $60.03 \pm 2.26 \mathrm{Aa}$ \\
Conventional & $41.29 \pm 1.89 \mathrm{Bb}$ & $48.22 \pm 3.55 \mathrm{Ba}$ \\
\hline $\boldsymbol{\beta}$-Carotene $\left(\boldsymbol{\mu \mathbf { g ~ g } ^ { - 1 } )}\right.$ & & \\
\hline Organic & $0.24 \pm 0.01$ & $0.27 \pm 0.01$ \\
Conventional & & $0.21 \pm 0.02$ \\
\hline Lycopene $\left.^{\dagger} \boldsymbol{\mu} \mathbf{g ~ g}^{-1}\right)$ & $0.16 \pm 0.02$ & \\
\hline Organic & & $0.53 \pm 0.02$ \\
Conventional & & $0.44 \pm 0.03$ \\
\hline
\end{tabular}

indicates difference between the crop systems; means followed by different lowercase letter in a column are different; means followed by different uppercase letter in a row are different (Tukey's test, $\mathrm{p}<0.05$ ). The results are expressed on a fresh weight basis. ('indica diferença entre os sistemas de cultivo; médias seguidas por diferentes letras minúsculas em uma coluna são diferentes; médias seguidas por diferentes letras maiúsculas em uma linha são diferentes (teste de Tukey, $\mathrm{p}<0.05$ ). Os resultados são expressos com base em peso fresco).

Chitarra \& Chitarra (2005), consumers associate color changes to increased sweetness and other desirable traits. Accordingly they usually select the most intensely colored fruits, which are not as bright. However, there is not always a direct correlation between color and quality.

Cherry tomatoes from all the treatments obtained a value of $15.9 \pm$ 5.7 for the $\mathrm{a}^{*}$ component (Table 1), which indicates green $\left(-a^{*}\right)$ to red $\left(+a^{*}\right)$ transition. This value is lower than that reported by Carvalho et al. (2005), who, despite having also analyzed the pulp of homogenized tomatoes, worked with different cultures and production conditions. The $\mathrm{b}^{*}$ component, which indicates blue $\left(-b^{*}\right)$ to yellow $\left(+b^{*}\right)$ transition, was around $29.3 \pm 7.5$ in all the groups (Table 1). This is close to the average of 26.75 reported in the literature for tomatoes (Carvalho et al., 2005). Neither cropping system nor harvesting time affected $a^{*}$ and $b^{*}$ components, suggesting that, according to this indicator, the maturation point of the fruit studied was standardized.

The levels of humidity, dry matter, carbohydrates, crude fiber, proteins, ashes, ethereal extract and energetic value of the cherry tomatoes were not affected by the treatments ( $>0.05)$. According to Worthington (1998), the nutrient content of vegetables is affected by soil characteristics, fertilization, crop management, climate and region. With respect to the present study, the effect of climate and general soil characteristics in each cropping system can be practically disregarded because the experiment was conducted in a homogeneous area with similar soil type. However, soil must be managed under conventional or organic practices for a determinate period of time until the effects of cropping system on nutritional changes in vegetables are identifiable (Borguini \& Torres, 2006). The present experiment used areas with a relatively brief history of organic cultivation, which probably explains the similarities between the characteristics of conventional and organic tomatoes.

Mean humidity $\left(93.0 \mathrm{~g}^{100 \mathrm{~g}^{-1}}\right)$

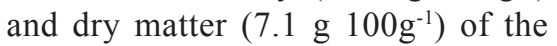
samples analyzed are in accordance with literature values for cherry tomatoes (Hernández Suárez et al., 2007). In addition, mean ash content $(0.5 \mathrm{~g}$ $\left.100 \mathrm{~g}^{-1}\right)$ was comparable to that found by Oke et al. (2005) for tomatoes, and carbohydrate content $(3.1 \mathrm{~g} 100$ $\mathrm{g}^{-1}$ ) was within the range of $3-3.5 \%$ reported for tomatoes (Moreira et al., 2005). However, fiber $\left(2.5{\left.\mathrm{~g} 100 \mathrm{~g}^{-1}\right)}^{-1}\right.$

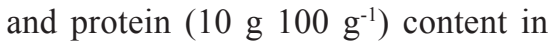
the present study was higher than that reported by Hernandez Suarez et al. (2007). These discrepant results are to an extent expected because, although the same crop was investigated, the studies compared were carried out under different crop and environmental

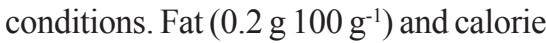

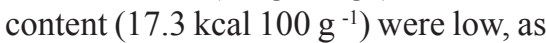
expected for this fruit (Nielsen, 1998).

Carotenoid, lycopene and $\beta$-carotene levels were generally higher in cherry tomatoes grown under organic cropping than in the conventional system (Table 2). Harvesting time also affected these variables, which increased over the experiment. Only total carotenoid content was affected by the interaction between production system and harvest time.

Similar results were reported by Caris-Veyrat et al. (2004), who also found higher carotenoid content, on a fresh weight basis, in organic tomatoes compared to conventionally-grown varieties. As aforementioned, the organic cropping system may account for the increase in carotenoid content, a finding supported by the reduced brightness ( $\mathrm{L}^{*}$ component) of organic cherry tomatoes. This result confirms the nutritional superiority of organically grown vegetables, considering the hypothesis that management practices and more modern agricultural supplies may have contributed to this finding. Earlier studies did not find that cropping system (organic vs conventional) affected lycopene and $\beta$-carotene levels in Débora and Carmen tomato cultivars (Borguini \& Silva, 2007). However, experimental conditions were different, including cultivar, sowing time, environment and cultivation conditions, which may influence carotenoid content in food (Rodriguez-Amaya, 1985).

According to Gómez et al. (1998) fruit color depends on total carotenoid at harvest time. Corroborating this theory, Carvalho et al. (2005) state that the color of homogenized tomato pulp is one of the best alternatives for indirectly estimating carotenoid content. Fruit color is used as a maturity indicator, which is also associated to lycopene and $\beta$-carotene synthesis as well as green color reduction (López Camelo \& Gómez, 2004). Despite these assumptions, the cherry tomatoes analyzed in the present study and harvested at 30 and 45 days had the same 
Table 3. Mean $( \pm \mathrm{sd})$ bioactive bioamines of cherry tomatoes $\left(\mathrm{mg} 100 \mathrm{~g}^{-1}\right)$ from conventional or organic cropping systems (aminas bioativas de tomate cereja cultivado em sistemas de produção orgânico e convencional). Montes Claros, UFMG, 2006.

\begin{tabular}{|c|c|c|}
\hline Bioamine (mg $100 \mathrm{~g}^{-1}$ ) & 30 days & 45 days \\
\hline \multicolumn{3}{|l|}{ Total Amine } \\
\hline Organic & $47.98 \pm 1.66 \mathrm{Ab}$ & $60.03 \pm 2.26 \mathrm{Aa}$ \\
\hline Conventional $^{\dagger}$ & $41.29 \pm 1.89 \mathrm{Bb}$ & $48.22 \pm 3.55 \mathrm{Ba}$ \\
\hline \multicolumn{3}{|l|}{ Putrescine } \\
\hline Organic & $1.35 \pm 0.35$ & $1.39 \pm 0.08$ \\
\hline Conventional & $1.04 \pm 0.37$ & $1.49 \pm 0.11$ \\
\hline \multicolumn{3}{|l|}{ Serotonine } \\
\hline Organic & $0.34 \pm 0.06$ & $0.43 \pm 0.19$ \\
\hline Conventional & $0.38 \pm 0.08$ & $0.46 \pm 0.1$ \\
\hline \multicolumn{3}{|l|}{ Spermidine } \\
\hline Organic & $0.97 \pm 0.20$ & $1.00 \pm 0.09$ \\
\hline Conventional $^{\dagger}$ & $0.68 \pm 0.09$ & $0.70 \pm 0.05$ \\
\hline \multicolumn{3}{|l|}{ Histamine } \\
\hline Organic & $0.92 \pm 0.21 \mathrm{Aa}$ & $0.98 \pm 0.11 \mathrm{Aa}$ \\
\hline Conventional & $0.44 \pm 0.12 \mathrm{Ba}$ & $0.22 \pm 0.02 \mathrm{Bb}$ \\
\hline \multicolumn{3}{|l|}{ Tyramine } \\
\hline Organic & $0.15 \pm 0.02 \mathrm{Aa}$ & $0.12 \pm 0.01 \mathrm{Bb}$ \\
\hline Conventional & $0.13 \pm 0.04 \mathrm{Ab}$ & $0.18 \pm 0.01 \mathrm{Aa}$ \\
\hline \multicolumn{3}{|l|}{ Agmatine } \\
\hline Organic & $0.05 \pm 0.01 \mathrm{Aa}$ & $0.06 \pm 0.01 \mathrm{Ba}$ \\
\hline Conventional & $0.05 \pm 0.02 \mathrm{Ab}$ & $0.09 \pm 0.01 \mathrm{Aa}$ \\
\hline \multicolumn{3}{|l|}{ Spermine } \\
\hline Organic & $0.15 \pm 0.02 \mathrm{Aa}$ & $0.12 \pm 0.01 \mathrm{Ab}$ \\
\hline Conventional & $0.11 \pm 0.0 \mathrm{Ba}$ & $0.13 \pm 0.01 \mathrm{Aa}$ \\
\hline \multicolumn{3}{|l|}{ Tryptamine } \\
\hline Organic & $0.44 \pm 0.10 \mathrm{Ab}$ & $0.63 \pm 0.06 \mathrm{Aa}$ \\
\hline Conventional & $0.36 \pm 0.06 \mathrm{Aa}$ & $0.37 \pm 0.06 \mathrm{Ba}$ \\
\hline
\end{tabular}

†indicates difference between the crop systems; means followed by different lowercase letter in a column are different; means followed by different uppercase letter in a row are different (Tukey's test, $\mathrm{p}<0.05$ ). The results are expressed on a fresh weight basis. (†indica diferença entre os sistemas de cultivo; médias seguidas por diferentes letras minúsculas em uma coluna são diferentes; médias seguidas por diferentes letras maiúsculas em uma linha são diferentes (teste de Tukey, $\mathrm{p}<0.05$ ). Os resultados são expressos com base em peso fresco).

coloration, but different carotenoid, lycopene and $\beta$-carotene levels, which were higher in the latter period $(\mathrm{p} \leq 0.05)$.

These results suggest that fruit coloration alone is not a reliable indicator of tomato maturity, as observed by Konrad (2002). Ripening heterogeneity of tomatoes (Carvalho et al., 2005) may disrupt the association between fruit color and carotenoid levels. At the first harvest ( $30^{\text {th }}$ day), a large number of green fruits was observed in the same trees from which the mature fruits were collected, which is consistent with the in food possess an intoxication risk to human health (Halász et al.; 1994, Glória, 2005).

In relation to the cherry tomatoes studied, only cadaverine and feniletilamine were not quantifiable (Table 3). Putrescine and serotonine levels were not affected by the factors studied ( $>0.05$ ), but total amine and spermidine content was higher in organically grown tomatoes compared to conventionally grown varieties $(p \leq 0.05)$. The effects of the interaction between harvest time and production system for histamine, tyramine, agmatine, spermine and tryptamine levels were different $(\mathrm{p} \leq 0.05)$.

The organic cropping system produced cherry tomatoes with higher total amine content than fruits from the conventional system. In both cropping systems, total amines increased from the first to the second harvest. One of the reasons for the accumulation of some biogenic amines in organic fruits is soil mineral deficiency (Angosto \& Matilla, 1993). The main problem of organic cropping is the low concentration of nutrients in organic fertilizers, which should be used in large amounts to meet crop needs. Moreover, organic fertilizers take longer to deliver certain nutrients (Fernandes et al., 2007), promoting bioamine production. Bioamine production increased in the 15-day interval between harvest times, showing that plants continue producing these compounds until fruits are collected at a more mature stage.

Histamine and tryptamine levels in the tomatoes increased from the $30^{\text {th }}$ to the $45^{\text {th }}$ experimental day, but only in organic tomatoes. The organically grown tomatoes generally had higher amine content than conventionally grown, a finding also observed for spermine levels harvested at 30 days. This was probably caused by the same factors described to explain total amine levels, i.e., this cropping system promotes amine production due to soil deficiencies and this synthesis continues until the fruit is harvested. Interestingly, histamine levels decreased in conventionally grown tomatoes from the first to the second harvesting.

Tyramine and agmatine levels were 
also higher in tomatoes harvested at 45 days than in tomatoes harvested at 30 days, but unlike the amines described, this effect was observed only in conventionally grown tomatoes. In organic tomatoes, agmatine levels were unchanged and tyramine decreased over the experiment. In cherry tomatoes collected at 45 days, the content of these amines was higher in conventionally grown tomatoes.

During the pre-growth phase, plant foods exhibit the highest amine content due to cell division processes, but these elements are lower during development and maturation (Halász et al., 1994). Amine content may also be increased by stress factors such as pathogen attack, mechanical damage, acidity, salinity, osmosis and mineral deficiency (Walters, 2003). Because these variables were not recorded in the present study, the present study cannot support any associations between stress and increases in amines such as tryptamine in organic tomatoes and tyramine and agmatine in conventionally grown fruits, from the first to the second harvesting. In the organic system, the biogenic amine tyramine showed an opposite result compared to the conventional system when taking into account its content during harvesting time, thereby showing how these factors influenced this characteristic.

Other studies show contrasting results, such as higher proportions of spermedine in vegetables grown in conventional cropping systems compared to those grown in organic systems (Rocha, 2006). However, this discrepancy may be related to a number of previously decribed variables as well as differences in extraction methods (Kalac \& Krausová, 2005), making any comparisons invalid.

Organically grown tomatoes are more nutritious than conventional cultivars because they contain $\beta$-carotene and lycopene. However, as a result, they are not as bright. The fact that carotenoid content and TSS were higher in tomatoes harvested at 45 days compared to those harvested at 30 days suggests that this 15-day ripening period is important for producing high- quality cherry tomatoes, especially when grown organically.

In addition, total bioactive amine levels were higher in organic tomatoes. These substances are important for the human metabolism, and the doses determined are nutritious and well below the intoxication level.

\section{REFERENCES}

ANGOSTO T; MATILLA JA. 1993. Variations in seeds of three endemic leguminous species at different altitudes. Physiologia Plantarum 87: 329-334.

AOAC. 2000. Association of Official Analytical Chemists. Official methods of analysis of the AOAC international. 17. ed. Washington, DC: AOAC.

BARDÓCZ S. 1995. Polyamines in food and their consequences for food quality and human health. Trends Food Science Technology 6: 341-346.

BORGUINI RG; TORRES EAFS. 2006. Alimentos orgânicos: qualidade nutritiva e segurança do alimento. Segurança Alimentar e Nutricional 13: 64-75.

BORGUINI RG; SILVA MV. 2007. O conteúdo nutricional de tomates obtidos por cultivo orgânico e convencional. Higiene Alimentar 21: 41-45.

BRASIL. 2003. Ministério da Agricultura, Pecuária e do Abastecimento. Lei Federal n. 10.831 de dezembro de 2003. Dispõe sobre normas para a produção de produtos orgânicos vegetais e animais. Diário Oficial da República Federativa do Brasil, Brasília, DF. Seção 1. p. 11.

CALIMAN FRB; MARIM BG; STRINGHETA PC; SILVA DJH; MOREIRA GR; ABREU FB. 2008. Relation between plant yield and fruit quality characteristics of tomato. Journal of Biosciense 24: 46-52.

CARIS-VEYRAT C; AMIOT MJ ; TYSSANDIER V; GRASSELLY D; BURET M; MIKOLJOZAK M; GUILLAND JC; BOUTELOUP-DEMANGE C; BOREL P. 2004. Influence of organic versus conventional agricultural practice on the antioxidant microconstituent content of tomatoes and derived purees, consequences on antioxidant plasma status in humans. Journal of Agriculture and Food Chemistry 52: 6503-6509.

CARVALHO W; FONSECA MEN; SILVA HR; BOITEUX LS; GIORDANO LB. 2005. Estimativa indireta de teores de licopeno em frutos de genótipos de tomateiro via análise colorimétrica. Horticultura Brasileira, 23: 819-825.

CHITARRA MIF; CHITARRA AB. 2005. Póscolheita de frutos e hortaliças: fisiologia e manuseio. 2. ed. Lavras: UFLA.

FERNANDES SBV; UHDE LT; WÜNSCH JA. 2007. A fertilidade do solo em sistemas de cultivos orgânicos de soja. Revista Brasileira de Agroecologia 2: 1541-1544.

FERREIRA MD; FRANCO ATO; KASPER RF; FERRAZI CO; HONÓRIO SL; TAVARES M.
2005. Post-harvest quality of fresh-marketed tomatoes as a function of harvest periods. Science Agriculture 6: 446-451.

GLÓRIA MBA. 2005. Amines. In: HUI H; NOLLET LL (eds). Handbook offood science. New York: Marcel Dekker, 2005. Cap. 13. p. 38.

GÓMEZ R; VARÓN R;AMO M; TARDÁGUILA J; PARDO JE. 1998. Differences in the rate of coloration in tomato fruit. Journal of Food Quality 21: 329-339.

GOULD WA. 1974. Tomato production, processing and quality evaluation. Westport: The AVI. 445 p.

HALÁSZ A; BARÁTH A; SIMON-SARKADI L; HOLZAPFEL W. 1994. Biogenic amines and their production by microorganisms in food. Trends in Food Science and Technology 5: 42-49.

HERNÁNDEZ SUÁREZ MH; RODRÍGUEZ RODRÍGUEZ EM; DÍAZ ROMERO C. 2007. Mineral and trace element concentrations in cultivars of tomatoes. Food Chemistry 104: 489-499.

IAL. 1985. Instituto Adolfo Lutz. Normas analiticas do Instituto Adolfo Lutz: métodos químicos e físicos para análises de alimentos. 3. ed. São Paulo: IMESP.

KALAC P; KRAUSOVÁ P. 2005. A review of dietary polyamines: formation, implications for growth and health and occurrence in foods. Food Chemistry 90: 219-230.

KOKUSZKA R. 2005. Avaliação do teor nutricional de feijão e milho cultivados em sistemas de produção convencional e agroecológico na região Centro-Sul do Paraná. Curitiba: UFPR. 113 p. (Tese mestrado).

KONRAD M. 2002. Efeito de sistemas de irrigação localizada sobre a produção $e$ qualidade da acerola (malpighia spp) na região da Nova Alta Paulista. Ilha Solteira: UNESP. 134 p. (Tese mestrado).

LENUCCI MS; CADINU D; TAURINO M; PIRO G; DALESSANDRO G. 2006. Antioxidant composition in cherry and high-pigment tomato cultivars. Journal of Agriculture Food and Chemistry 54: 2606-2613.

LIMA A; SILMA AMO; TRINDADE RA; TORRES RP; MANCINI-FILHO J. 2007. Composição química e compostos bioativos presentes na polpa e na amêndoa do pequi (Caryocar brasiliense). Revista Brasileira de Fruticultura 29: 695-698.

LÓPEZ CAMELO AF; GÓMEZ PA. 2004. Comparison of color indexes for tomato ripening. Horticultura Brasileira 22: 534-537.

MARIM BG; SILVA DJH; GUIMARÃES MA; BELFORT G; TEIXEIRA MB. 2001. Sistemas de condução de tomateiro visando produção na primavera e verão. Horticultura Brasileira 19: 227.

MERCADANTE AZ; RODRIGUEZ-AMAYA DB; BRITTON G. 1997. HPLC and mass spectometric analysis of carotenoids from mango. Journal of Agriculture and Food Chemistry 45: 120-123.

MOREIRA O; CARVAJAL A; CABRERA L; CUADRADO C. 2005. Tablas de composición de alimentos. Madrid: Pirámide, 248 p. 
NIELSEN SS. 1998. Food analysis. 2. ed. Gaithersberg: Aspen. 630 p.

OKE M; AHN T; SCHOFIELD A; PALIYATH G. 2005. Effects of phosphorus fertilizer supplementation on processing quality and functional food ingredients in tomato. Journal of Agricultural and Food Chemistry 53: 1531-1538.

ROCHA SA. 2006. Caracteristicas bioquímicas em cascas, folhas e talos de vegetais póscolheita em sistema de produção convencional e orgânico. Botucatu: UNESP. 63 p. (Tese mestrado).
RODRIGUEZ-AMAYA DB. 1985. Os carotenóides como precursores de vitamina A. Boletim da Sociedade Brasileira de Ciência e Tecnologia de Alimentos 19: 227-332.

RODRIGUEZ-AMAYA DB; KIMURA M. 2004. HarvestPlus handbook for carotenoid analysis. Washington: IFPRI CIAT, $58 \mathrm{p}$. (HarvestPlus technical monograph, 2).

VALE SR; GLÓRIA MB. 1997. Determination of biogenic amines in cheese. Journal of AOAC International 80: 1006-10012.

WALTERS D. 2003. Resistance to plant pathogens: possible roles for free polyamines and polyamine catabolism. New Phytologist, 159: 109-115.

WORTHINGTON V. 1998. Effect of agricultural methods on nutritional quality: a comparison of organic with convencional crops. Alternative Therapies 4: 58-69.

YAHIA EM; CONTRERAS-PADILLA M; GONZÁLEZ-AGUILAR G. 2001. Ascorbic acid content in relation to ascorbic acid oxidase and polyamine content in tomato and bell pepper fruits during development, maturation and senescence. Lebensmittel-Wissenschaft und Technologie 34: 452-457. 